\title{
Social Appropriation of Internet Technology: a South African platform
}

\author{
G. J. Erwin \\ Cape Peninsula University of Technology < erwing@ctech.ac.za $>$ \\ W.J.Taylor \\ Cape Peninsula University of Technology < $\underline{\text { taylorw@ctech.ac.za }}>$
}

\begin{abstract}
The social appropriation of Internet technologies is emerging as a research and practice field called Community Informatics (CI). Various research groups (for example Australia, UK, Canada, Latin America, Italy etc.) are contributing to Government's gradual realisation that the enabling of communities with Internet technologies can boost local economic and social development, as well as enhance personal empowerment. Civil society digital inclusion, linked with World Summit on the Information Society (WSIS), is now seen as a necessary component of social development strategy. However, various attempts at such initiatives have met different forms of resistance and various levels of success. Cape Peninsula University of Technology is establishing a research hub in Cape Town as part of the international CIRN (Community Informatics Research Network). This project will aim to establish a research, teaching and community engagement platform in Community Informatics (the social appropriation of Internet Technologies for local benefit) which will link Cape Peninsula University of Technology into a rapidly expanding international area of research and teaching as well as putting it into a national leadership position. Outputs will include demonstrated linkages with local, national and international Community Informatics efforts, the establishment of local projects and entities, the establishment of courses, the attraction of undergraduate and post graduate students, a profile with national and international funding agencies, publications, funding proposals, internal agency recognition in research and teaching, a program of high profile and internationally recognised visiting research fellows and academic sabbaticals. This paper discusses activities towards this South African initiative and experience elsewhere.
\end{abstract}




\section{Introduction and Background}

Information and Communication Technologies (ICTs) are posing fundamental questions for society, government and commerce in economic, social, educational, cultural and democratic processes within and across nation states in terms of access, equity and security. Electronic networks which can operate both inside and outside of nation states with hitherto unknown volume and velocity are challenging and changing the architecture of governance, power and culture (Bollier, 2003, Coleman and Gotze, 2002; Rheingold, 2004 )

Many governments and global agencies have recognised the growing issues associated with inequitable ICT access and have provided funded programs aimed at addressing specific needs within nation states. However, there is growing evidence that many of these programs have failed to deliver on their desired aims and that the societal and community-based disadvantages resulting from uneven societal adoption of ICTs are growing (see for example Pigg, 1998; Hewitt and Pinder 2003; Clement, 2000; Gurstein 2003a, 2003b). There is now increased understanding that the provision of ICTs access, either high or low capacity, through government and private sector efforts by itself is insufficient to address the substantial concerns that face society as a direct result of ICTs (Gurstein, 2003a; Pinder and Hewitt, 2002).

Further, growing experience across the world in the application of ICTs in the provision of government services (known as e-government), is showing that the electronic provision of government information and service as for example, through currently available physical ICT access within particular communities, does not appear to be sufficient to meet the broad challenges governments must address for individual societies to move forward in the information economy (Hewitt and Pinder, 2003). In almost all jurisdictions across the world, the take up of electronically enabled government services has been well below expectations even in situations where there are high levels of income, education and Internet connection across their populations (Bertucci, 2003; Dutta, Lanvin and Paua, 2003; Riley, 2003a; Rohleder and Jupp, 2003; West, 2003). Fundamental to these issues is the recognition of concepts of:

- Effective use as opposed to access (whether this is based around physical, attitudinal, educational, disability, cultural, or integration concepts)

- Civil Society and a new contract that binds civil society, public and private sectors into a value matrix (Brussels-EU Chapter of the Club of Rome and Factor 10 Institute, 2002)

These issues provide substantial challenges for the traditional and familiar forms of governance and business education, as well as for issues related to the form and function of service delivery and forms of engagement with citizens, the private sector and civil society. The traditional incrementalist and efficiencybased approaches within specialist agency structures are now under pressure from increasingly ubiquitous ICT applications that have little respect for professional, organisational, nation state, social or cultural boundaries.

In recognizing these issues and their impacts on the developing world the United Nations (UN) through the International Telecommunications Union (ITU) delivered the first World Summit on the Information Society (WSIS; http://www.itu.int/wsis ) in Geneva in December 2003. Fundamental to this event and the planning for the next WSIS in Tunis 2005, is the recognition of the concept of civil society alongside business and government as a triumvirate to deal with the huge problems of inequity that ICTs are delivering across the world. In defining responsibility for civil society, planning processes have clearly defined higher education as an essential leader.

\section{The emerging context for Social Appropriation of ICTs}

ICTs are simultaneously both incrementally and fundamentally changing the working, social and personal lives of many people in developed countries and developing countries alike. The technologically deterministic view of ICT diffusion, particularly in the development of e-government, is now being 
challenged. As the many examinations of 'e-readiness' are finding, the major current impediments to adoption of e-government are in the demand and the aggregation of supply and demand domains. Many of the ICT applications developed for organizational use have not been successfully embedded into the demand and demand aggregation domains and are being found wanting in such areas. Hence the social appropriation of ICTs refers to the duality of redefining application design and of embedding the technology in social processes in civil society (for example see Surman and Riley, 2003). In short it is about customer-driven technology.

In beginning to examine the emerging frame for ICTs in a societal sense as opposed to a technology or organizational-efficiency lens, it is useful to consider the comparatively recent evolution of Information Systems (IS) as a discipline and its alignment with Management Information Systems (MIS). This can then act as a basis for examining the emergence of Community Informatics Systems (CIS) and Civil Society (CS) as a key area of the Information Society. IS has been the overarching term used to describe the information software systems used for organisational applications. The traditional discipline of Information Systems is currently undergoing a major evolutionary step into societal applications; as opposed to organizational applications in business, education and service delivery. Harris (2002) has proposed a discussion framework for the emergence of Information Systems as a discipline (see Table I). While the time frames therein can be considered approximate, depending upon location, and the descriptors used are unnecessarily prescriptive Harris does, nonetheless, chart a development base for Information Systems as a discipline. The point that the Information Systems discipline is now increasingly moving outside of organisational boundaries and into society is also made. This society domain is much more difficult to define in terms of both form and function at the operational level. In doing so, Information Systems is mixing with hitherto separate and unfamiliar disciplines that include community engagement.

\begin{tabular}{|c|c|c|c|c|}
\hline $\begin{array}{l}\text { Dominant } \\
\text { Technology }\end{array}$ & $\begin{array}{l}\text { Information } \\
\text { Systems Locus }\end{array}$ & $\begin{array}{l}\text { Work group } \\
\text { focus }\end{array}$ & $\begin{array}{l}\text { Dominant } \\
\text { referent } \\
\text { discipline }\end{array}$ & Scope \\
\hline $\begin{array}{l}1960-70 \\
\text { Main Frame } \\
\text { Computers }\end{array}$ & $\begin{array}{l}\text { Electronic Data } \\
\text { Processing }\end{array}$ & Clerical Staff & Computer Science & \multirow[t]{4}{*}{$\begin{array}{l}\text { The } \\
\text { Organisation }\end{array}$} \\
\hline $\begin{array}{l}\text { 1970-80 } \\
\text { Mini-Computers }\end{array}$ & $\begin{array}{l}\text { Management } \\
\text { Information Systems }\end{array}$ & Managers & Management & \\
\hline $\begin{array}{l}\text { 1980-90 } \\
\text { Personal Computers }\end{array}$ & End User Computing & $\begin{array}{l}\text { Knowledge } \\
\text { Workers }\end{array}$ & $\begin{array}{l}\text { Organisational } \\
\text { Behaviour }\end{array}$ & \\
\hline $\begin{array}{l}1990-2000 \\
\text { Networks }\end{array}$ & $\begin{array}{l}\text { Strategic Information } \\
\text { Systems }\end{array}$ & Shareholders & $\begin{array}{l}\text { Economics and } \\
\text { Marketing }\end{array}$ & \\
\hline $\begin{array}{l}2000 \\
\text { The Internet }\end{array}$ & $\begin{array}{l}\text { Community } \\
\text { Informatics }\end{array}$ & Citizens & Social Science & Society \\
\hline
\end{tabular}

Table I: Information Systems as an Emerging Discipline

Source: Harris (2002)

The term Community Informatics (Gurstein, 2000) has recently emerged to describe the use of ICTs for local community benefit and more recently, international researchers and funding agencies have moved towards the term Community Informatics Systems (CIS) as a parallel for Management Information Systems (MIS). CIS is an emerging area of practice, teaching and research that fits within an Information Society framework alongside the more traditional areas of Business, Technology, Government service delivery and Contemporary Communication. There are several very distinct differences between MIS and CIS approaches. Community Informatics Systems focus on distributed systems and not aggregated ones. CIS favours collaboration over competition and sharing over hoarding. CIS is based on a premise of active interaction in the development, use and appropriation of the systems, compared to MIS which is predominantly based on a passive consumption of service offerings (Gurstein, 2003b). 


\section{The role of higher education}

There have been increasing calls over recent times for Universities to recognise their responsibilities in regard to life long learning in their communities (Cumpston et al., 2001; Garlick, 1998; Gronski \& Pigg, 2000; Harkavy, 1998; Nyden, 2001; Rice, 1996). In particular, there is discussion on the role of higher education in providing capacity to communities to address the imbalances between the private, public and the community sectors in the basic operations of a democratic society; facilitating an attitudinal change in graduates towards community service; and in aligning some of their research programs to address 'real' issues confronting particular communities (Garlick, 1998; Gronski \& Pigg, 2000; Harkavy, 1998; Nyden, 2001; Nyden et al., 1997; Schuler, 1997, 2001). Underlying these issues is a fundamental challenge to Universities to revisit the issues of plurality and local relevance from whence many of them have come (Rice, 1996). CI goes to the very heart of these above mentioned calls because effective communication at the community level is the collective base for learning which combines science with practice as an essential core component. In recognition of the importance of readdressing this leadership vacuum in the United States, more than 850 Universities have joined the University Compact (http://compact.org) with the overarching aim of building social responsibility into teaching and research in order to better equip their graduates and society for an increasingly positive engagement in shaping their collective community futures. The social appropriation of ICTs quite clearly has a very important role in achieving these aims and is vital to effective self reliance in the developing world. Such matters are increasingly being recognized across the developed and developing world including significant examples of University/Community partnerships for the social appropriation of ICTs and Community Informatics research to determine the key issues that will allow communities to become more self-reliant in the digital exist in both situations.

The work of the COIN Internet Academy (http://capricornia.org) and the Centre for Community Networking Research (http://www.ccnr.net.au ) in Australia, the Canadian Research Alliance for Community and Innovative Networking (CRACIN; http://www.cracin.ca), the Community Network Analysis project in Brighton UK (http://www.cna.org.uk/) are examples of the research based approaches that a number of Universities are taking to examine the social appropriation of ICTs and Community Informatics. Such activities form the basis of the Community Informatics Research Network (CIRN; http://www.ciresearch.net) which involves more than 200 researchers from more than 20 countries to coordinate, share and develop useful research that will complement the enormous energy that has been applied to the organizational appropriation of ICTs in government and business across the world.

\section{Key Elements in the social appropriation of ICTs}

Taylor (2004) shows key elements for CI policy, praxis and research:

- ICT competency as an essential life skill

- Trust

- Discontinuity of ICT adoption

- Collaboration of civil society, government and business sectors

- Perceived relevance

- Information granularity

- Spatial dimension

- Assessment, policy and research

In preparing for the next phase of the emerging ICT-enabled environment, a new social contract is required that binds and partners civil, private and public sectors in delivering social inclusion and social cohesion in ways that strengthen economic, social and cultural benefit in the information society.

In the context of the Information Society, as defined by the United Nations and its related international bodies and task forces, the emergence of a construct of civil society is clearly the preferred option for all of 
the significant international bodies with an interest in broad-based access to, and the effective use of ICTs (Birch, 2003; Bloem, Guerra, Krebs and Lassonde, 2004; O'Siochru and Constanza-Hock, 2003; Thompson, 2004; WSIS, 2003; WSIS Civil Society Plenary, 2003). Tentative first steps have been taken in this regard in Australia with the formation in 2003 of the Roundtable for Australian Civil Society (RACS, 2003) to develop and deliver a statement from Australian Civil Society to the World Summit on the Information Society (WSIS). Equally in this context, Governments should aim to achieve the considerable public value which could be realized from representing themselves as members of networks instead of levels of hierarchies.

In putting forward such a distributed agenda of participation and involvement, there is a need for both a recognisable form, through a visible and supported structure, and function, through a distributed research and policy development capacity. Such a forum/academy should sit alongside government and act as:

- $\quad$ an open channel for discussion

- a primary developer of relevant inputs to policy

- a coordinator and evaluator of research, and

- an alliance builder with relevant international efforts.

This approach will provide the means to continually advance a 'joined up' agenda which recognises the needs of various societal layers or segments, the value of participation in gaining increased effective use of ICTs and the high costs of retro-designing for ubiquitous electronic interaction.

\section{The vision for CI @ Cape Peninsula University of Technology}

Cape Peninsula University of Technology has established a Business Applied Research Centre (BARC) to align its research energies and graduate competencies with national and regional business and community needs. Under the umbrella of a (South Africa) National Research Foundation (NRF) research niche area for e-commerce in Small Medium and Micro Enterprises,(SMMEs), many projects are running, including those in the fields of health informatics for Small/Medium Medical Practices, success metrics for e-commerce SMMEs and adoption of e-commerce by SMMEs. These projects are clearly aligned with a Community Informatics theme for empowering local communities using Information and Communication Technologies (ICTs). The new initiative in joining and contributing to CIRN will supply strong focus on the emergence of ICTs into civil society issues, such as poverty alleviation, policy formulation and reduction of employment. These efforts will attract partners throughout Africa.

Another Cape Peninsula University of Technology initiative called e-iKamva has already begun as a pilot project to provide access to skills training and technology for disadvantaged residents of Cape townships as a step towards economic self-sufficiency from small business operation.

The large group of researchers in CIRN (Community Informatics Research Network, internationally and now in Cape Town) will work with Cape Peninsula University of Technology to create a model Community Informatics post-graduate curriculum suitable for Masters and Ph.D students, as well as short courses in CI for community practitioners and policy makers. The process of development of the curriculum will be one which both transfers international experience (research and practice) and works with local communities and community technology practitioners to reflect local needs as understood and articulated by the diverse range of local South African communities as they are given an opportunity to engage with and appropriate ICTs.

The developed curriculum and student learning will link into a range of community based technology initiatives within a context of Community Informatics research. In this way student learning will both incorporate the highest level of academic/professional content and a direct experience and involvement in community-based technology practice. The development of these programs will be sensitive to the requirements for community specific cultural, linguistic, and gender applications. 
An element of this approach will be that Cape Peninsula University of Technology students will have access to a range of learning and research opportunities both direct and electronically mediated with the other centres worldwide currently active in the CIRN network. Staff and student exchanges on communitybased projects and research will be targeted.

Among the areas that will be included in Cape Peninsula University of Technology's CI approach are:

- community research methodologies

- approaches and methodologies for CI sensitive policy analysis and development

- the development of contextual community responsive technology, and

- strategies for effective use of ICTs within a community practice context.

Other significant aspects of the community informatics approach include the development of strategies for the analysis of community and social requirements for designing community based processes of technology appropriation and planning; technology program planning and outcomes evaluation research. Professor Taylor, a co-author, has been instrumental in launching successful CI initiatives in Australia and elsewhere. His experience and CIRN contacts form a platform for CI to become a community-focused research hub at Cape Peninsula University of Technology. His several visits to South Africa have already enabled him to assess the resources, partnerships and goals of the Community Informatics project based at Cape Peninsula University of Technology.

Partnerships with government, civil society, business and industry are being sought to develop this CI focus for the empowerment of local communities via ICTs using BARC and other bodies as vehicles. Cape Peninsula University of Technology and Peninsula Technikon are merging in January 2005 to form the Cape Peninsula University of Technology (CPUT). Community Informatics will form a strong central component of CPUT's future vision. The purpose of a University is to protect and develop society by producing active, skilled citizens with adaptability and entrepreneurial approaches. Community Informatics supports this purpose directly. 


\section{References}

Bertucci. G. (2003). World Public Sector Report 2003: E-Government at the crossroads. United Nations, New York. ISBN 9211231587.

http://unpan1.un.org/intradoc/groups/public/documents/un/unpan012733.pdf . Accessed March 2004.

Birch, S. (2003). Civil Society Essential Benchmarks for WSIS. http://www.itu.int/wsis. Go to Civil Society Declarations under first phase. Accessed March 2004.

Bloem, R. Guerra, Krebs, V. and R. Lassonde, L. Report on the transition period between Phase I and 2 for WSIS. Posting to the bureau@wsis-cs.org list.16 March 2004

Bollier, D. (2003). The Rise of Netpolitik; How the Internet is changing international politics and diplomacy. A report to the $11^{\text {th }}$ annual Aspen Institute roundtable on Information Technology. Washington, DC. Aspen Institute. ISBN 089843368 1. http://216.181.117.89/index.asp?bid=1290 . Accessed 7 March 2004.

Brussels-EU Chapter of the Club of Rome and 'Factor 10 Institute (2002) Visions and Roadmaps for Sustainable Development in a Networked Knowledge Society”. Report of a workshop,' February 2002

Carey, K. (2004). Boosting Take Up means Ensuring Access for All. Speech given at the E-Government Seminar on 'Practical ways to boost take-up of e-Government Services. http://www.electronicgovernment.com/takeup.htm Accessed March 2004.

Coleman, S. and Gotze, J. (2002) Bowling Together: Online Public Engagement in Policy Deliberation. http://www.bowlingtogether.net/about.html Accessed March 2004.

Clement, A. and Shade, L. (2000) The Access Rainbow: A social/technical architecture for community networking, in Michael Gurstein (Editor) Community Informatics: Enabling Communities with Information and Communications Technologies, Idea Group Publishing, Hershey, USA, pp. 32-51.

Dutta, S., Lanvin, B and Paua, F. (2003). The Networked Readiness Index 2003-2004. http://www.weforum.org/site/homepublic.nsf/Content/Global+Competitiveness+Programme\%5CGlob al+Information+Technology+Report . Accessed March 2004

Executive Secretariat Lyon Summit. (2003). Lyon Declaration. http://www.cities-lyon.org/en/declaration . Accessed March 2004.

Falconer, D., J, Castleman, T., McKay, D., \& Altmann, G. (2000). Critical Approaches to Information Systems Planning: Refining the research agenda. Paper presented at the Americas Conference on Information Systems, Long Beach, CA

Feenberg, A and Bakardjieva, M. (2004). Virtual Community:no killer implication. New Media \& Society. 6(1) 37-43. Sage Publications, London.

Figueroa, M.E., Kincad, A.L.Rani, M. and Lewis, G. (2002). Communication for Social Change: An integrated model for measuring the process and its outcomes. John Hopkins University Centre for Communications Programs. The Rocckefeller Foundation, New York. NY.

Garlick, S. (1998). Creative Associations in Special Places: Enhancing the partnership role of Universities in Building Competitive regional economies. Dept Education Employment Training and Youth Affairs (DETYA). Canberra

Griffiths, M. (2004) Connecting Democracy to the Internet. Australian Financial Review. $20^{\text {th }}$ February. http://www.afr.com. 
Gronski, R., \& Pigg, K. (2000). University and community collaboration. The American Behavioral Scientist, 43(5), 781-792.

Gurstein, M. (2000). Community Informatics: Enabling Communities with Information and Communications Technologies Idea Group Publishing, Hershey, USA,

Gurstein, M. (2003a). Effective Use: A community informatics strategy beyond the digital divide. http://www.firstmonday.dk/issues/issue8_12/gurstein . Accessed March 2004.

Gurstein, M. (2003b). Community Innovation and Community Informatics: Building national innovation capacity from the bottom up. Keynote address ITiRA 2003 Conference. Caloundra. 15-17 December.

Harkavy, I. (1998). School-Community-University Partnerships: Effectively Integrating Community Building and Education Reform. Paper presented at the Connecting Community Building and Education Reform: Effective School, Community, University Partnerships - A Joint Forum of the U.S. Department of Education, U.S. Department of Housing and Urban Development, Washington, DC. July.

Harris, R. (2002). Research Partnerships to Support Rural Communities in Malaysia With Information and Communication Technologies. In J. Lazar (Ed.), Managing IT/Community Partnerships in the 21st Century. Hershey, PA: Idea Group Publishing.

Hewitt, P. and Pinder, A. (2003) UK Online Annual Report 2003. http://www.eenvoy.gov.uk/Home/Homepage/fs/en . Accessed March 2004.

Hunter, D. and Jupp, V. (2001) E-Government Leadership. Rhetoric vs Reality -Closing the Gap. http://www.accenture.com/xdoc/en/industries/government/final.pdf Accessed March 2004.

Huta, P (2004). Is there a role for ICTs in building and maintaining Social Capital? Connecting Up Conference Adelaide, 3-4 May, 2004. Http://www.communIT.info/conference

Larsen, E. and Rainie, L. (2002) The Rise of the E-Citizen: How People Use Government Agencies' Web Sites. http://www.pewinternet.org Accessed April 2004.

Mick, D. G., \& Fournier, S. (1998). Paradoxes of technology: Consumer cognizance, emotions, and coping strategies. Journal of Consumer Research, 25(2), 123 -144.

Moore, G.A. (1991). Crossing the Chasm. New York. Harper Business

Nyden, P., Figert, A., Shibley, M., \& Burrows, D. (1997). Building Community: Social Science in Action. Thousand Oaks, CA: Pine Forge Press.

O’Siochru, S. and Constanza-hock, C (2003). Global Governance of Information and Communication Technologies: Implications for transnational civil society networking. . http://www.ssrc.org/programs/itic . Accessed March 2004

Pigg, K. (1998) Missouri Express: Program Implementation and Assessment. Columbia. University of Missouri

Pinder, A. and Hewitt, P. (2002) UK Online Annual Report 2002. http://www.eenvoy.gov.uk/Home/Homepage/fs/en. Accessed March 2004

Rechsel, A.H., Kies, R., Mendez, F. And Schmitter, P.C. (2004) Evaluation of the Use of New Technologies in Order to Facilitate Democracy in Europe. http://c2d.unige.ch/int/OverviewInstits/Main_Report_final\%201.pdf. Accessed March 2004.

Rheingold. H. (2002) Smart Mobs: the next social revolution. Cambridge, MA Perseus Publications. ISBN 0738206083

Rice, R. E. (1996). Making a Place for the New American Scholar (1). Washington, DC: American Association for Higher Education.

Riley, T.B. (2003a) The Information Society: The role of information in the emerging global eGovernment, E-Governance and E-Democracy environments. Commonwealth Centre for EGovernance, Ottawa. http://www.electronicgov.net/pubs/index.shtml Accessed March 2004 
Riley, T.B. (2003b) E-Government vs E-Governance: Examining the differences in a changing public sector climate. Commonwealth Centre for E-Governance, Ottawa. http://www.electronicgov.net/pubs/index.shtml Accessed March 2004

Riley, T.B. and Riley C.G. (2003). E-Governance to E-Democracy: Examining the evolution. Commonwealth Centre for E-Governance, Ottawa. http://www.electronicgov.net/pubs/index.shtml Accessed March 2004

Riley, T.B. (2004) report on e-Democracy Seminar. Brussles. 12-13 February. http:/www.electronicgov.net/pubs/research_papers/brussels/brussels.shtml Accessed March 2004

Roundtable for Australian Civil Society (RACS) (2003). Statement from Australian Civil Society to the World Summit on the Information Society (WSIS). http://www.ciresearch.net . Accessed March 2004.

Rohleder.S.J. and Jupp, V. (2003) . E-Government LeadershiP; Engaging the customer. http://www.accenture.com/xd/xd.asp?it=enweb\&xd=industries\%5Cgovernment\%5Cgove_capa_egov.x $\underline{\mathrm{ml}}$ Accessed March 2004

Schuler, D. (1997). Community Computer Networks: An opportunity for collaboration among democratic technology practitioners and researchers. Paper presented at the Technology and Democracy, Oslo, Norway.

Schuler, D. (2001). Cultivating Society's Civic Intelligence: Patterns for a new world brain. Information , Communication and Society, 4(2), 157-181

Shergold, P (2004). Connecting Government: Whole-of-Government Responses to Australia’s Priority Challenges. Management Advisory Committee Report No 4. Department of Prime Minister and Cabinet, Canberra

Shergold, P. (2003) A Foundation of Ruined Hopes ? Delivering Government Policy. http://www.pmc.gov.au/docs/shergold151003.cfm . Accessed March 2004.

Surman, M. and Reilly, K. (2003) Appropriating the Internet for Social Change: towards th strategic use of networked technologies by transnational civil society organizations. http://www.ssrc.org/programs/itic . Accessed March 2004.

Taylor, W. (2004) Building Smart Communities for the Information Age. Putting People at the Centre of the Information Society (PPACIS). COIN Internet Academy, Central Queensland University.

Taylor, W. and Marshall, S. (2004) Community Informatics Systems: a meeting place for useful research. In P. Day and D. Schuler (Eds) Community Practice in the Network Society: Local action/global interaction. London, Routledge. forthcoming

Thompson, I. (2004) A report on World Summit on the Information Society. Pers. comm. Ian Thomson [ithomson@lycos.com].

Ward. M. (2004). What the net did next. BBC News. $1^{\text {st }}$ January. http://news.bbc.co.uk/go/pr/fr//2/hi/technology/3292043.stm . Accessed March 2004.

West. D.M. (2003). Global E-Government. Center for Public Policy, Brown University, Providence, Rhode Island. http://www.insidepolitics.org/egovt03int.html Accessed March 2004.

WSIS (2003) Declaration of Principles and Action Plan. . http://itu.int/wsis . Go to first phase. Accessed March 2004.

WSIS Civil Society Plenary (2003). Civil Society Declaration to the World Summit on the Information Society. http://itu.int/wsis . Go to Civil Society Declarations under first phase. Accessed March 2004. 